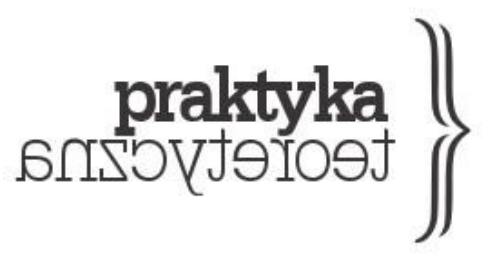

\title{
O ZNIESIENIU PRACY AKADEMICKIEJ. STOSUNEK MIĘDZY PRACOWNIKAMI INTELEKTUALNYMI A INTELEKTUALNOŚCIĄ MASOWĄ
}

RICHARD HALL

PRZEŁOŻYL: KRYSTIAN SZADKOWSKI

\begin{abstract}
Abstrakt: Niniejszy artykuł analizuje sposób, w jaki praca akademicka, rozumiana jako działalność wytwórcza, zostaje podporządkowana obiegom i cyklom kapitału finansowego. Obiegi te, jak twierdzę, redefiniują uniwersytety jako transnarodowe stowarzyszenia kapitałów, w ramach których konkretne i abstrakcyjne aspekty rzeczywistości pracy akademickiej ulegaja przekształceniu w celu wytwarzania wartości i akumulacji. Jeden ze sposobów na podjęcie krytyki oraz wyjście poza tego rodzaju rekompozycję wiedzie poprzez ponowne przyjrzenie się pracy akademickiej jako sfetyszyzowanej formie pracy, a następnie ujmowanie jej w kategoriach „intelektualności masowej”. Potencjał „intelektualności masowej” w kontekście możliwości wyzwolenia od dominacji kapitalistycznych stosunków społecznych został w niniejszym artykule zakwestionowany, jednak sama idea społecznie użytecznej, żywej wiedzy oferuje naszym zdaniem mechanizm umożliwiający przemyślenie wartości pracy akademickiej oraz wskazuje na możliwość jej zniesienia. Wobec tego, w artykule zadane zostało pytanie o to, czy możliwe jest rozpuszczenie pracy akademickiej, jako pracy intelektualnej, w obrębie tkanki społecznej, i odsłonienie w ten sposób innego obrazu społeczeństwa i produkcji społecznej. W tym miejscu idee otwartego kooperatyzmu i odważnej praktyki stają u podstaw polityki sojuszu przeciwko kapitałowi - polityki, która poszukuje sposobu na zniesienie istniejącego stanu rzeczy.
\end{abstract}

Słowa kluczowe: praca akademicka, intelektualność masowa, otwarty kooperatywizm, uniwersytet, wartość 


\section{Wprowadzenie}

Pracownik akademicki coraz częściej nie posiada żadnej dostrzegalnej autonomii poza możliwością tymczasowej poprawy swoich stosunków z kierownictwem Uniwersytetu, które rządzi nim zgodnie z logiką akumulacji, utowarowienia i maksymalizacji zysku (McGinn 2012). Prorynkowi zarządcy Uniwersytetu to nie tylko kanclerze. W ich skład wchodzą również ustawodawcy, właściciele funduszy private equity, agencje ratingowe, firmy technologiczne i wydawcy, a pośrednio również płacący czesne studenci (Hall 2013; McGettigan 2013). Ta transnarodowa sieć podmiotów tworzy stowarzyszenie kapitałów (Ball 2012; Marks 1977; Robinson 2004), który podporządkowuje i dyscyplinuje pracę akademicka.

Zrodzona w ten sposób subsumcja pracy akademickiej zachodzi w ramach „społecznej tyranii wartości wymiennej” oraz motywu zysku (Wendling 2009, 52). Na naszych oczach, za pośrednictwem globalnego arbitrażu pracy, outsourcingu i prekarności, wyłania się bowiem alienacja pracy akademickiej wdrażana za pośrednictwem grodzeń i utowarowienia jej wytworów i stosunków (Neary 2012). Ten nacisk na produkcję dla wymiany wspierany jest następnie przez kulturowe imperatywy studenta-jako-konsumenta, rankingów, miar wpływu czy wymiany wiedzy (Willetts 2013), oraz ekonomiczną wartość wyższego wykształcenia (Snowden 2013; Willetts 2014). Czy sprzeciwiając się tej tyranii grodzenia, można dziś odmiennie określić społeczną wartość pracy akademickiej, pod względem jej siły roboczej, wytworów badania i kształcenia, które tworzy, oraz stosunków, które utrzymuje i zachowuje?

Tego rodzaju próba wymaga, by naukowcy wyobrazili sobie, że ich umiejętności, praktyki i wiedza mogą być współdzielone i wykorzystane wspólnie oraz użytkowane w ramach szeroko pojętej kooperacji, stając się formą masowej intelektualności (Manzerolle 2010; Virno 2001). Wymaga to od akademików zrozumienia mechanizmów, na mocy których kapitał kooptuje żywą wiedzę, wytwarzaną przez ich siłę roboczą w postaci intelektu powszechnego (Marks 1986). Tego rodzaju kooptacja akademickich praktyk, dokonywana wskutek procesów grodzenia i utowarowienia, obejmuje: transfery wiedzy oraz wykorzystanie patentów; miary wpływu wyników badań; koncentrację na zadowoleniu studentów oraz analizowaniu kształcenia, by napędzać rozwój pedagogiczny; instytucjonalne wymuszanie pułapów osiągnięć w celu stosowania systemów zarządzania kształceniem, do spółki z politykami dotyczącymi wykorzystania mediów społecznościowych; zastosowanie metodologii zarządzania projektami i programami. Tego rodzaju zajęcia przekształcają siłę roboczą pracowników akademickich w jedna z form intelektu powszechnego, taką, która może zakrzepnąć wewnątrz technicznych i organizacyjnych innowacji umożliwiających wytwarzanie wartości (Virno 2004).

Odpierając tę kooptację i alienację, można z korzyścią odzyskać ideę intelektu powszechnego jako formy intelektualności masowej, czyli uspołecznionej wiedzy, będącej bezpośrednią, społeczną siłą wytwórczą. Masowa intelektualność jest społecznie użyteczną 
wiedzą, która wyłania się z definicji alternatywnej formy wartości, funkcjonującej jako społeczna reprodukcja odmiennego społeczeństwa (Harvey 2010). Dostarcza nam wartościowego kontrapunktu względem zarówno fetyszyzowania technologii, jak $i$ „niematerialnej” produkcji i akumulacji wartości (Manzerolle 2010; Marks 1968). Wobec tego, w kontekście rozwijania rzeczywiście istniejącej intelektualności masowej, akademicy moga zapytać, czy możliwe jest przeżywanie i opowiadanie odmiennej, jawnie politycznej historii pracy akademickiej w kontekście jej stosunków z tym, co społeczne.

Nacisk kładziony na politykę i organizację oznacza skupienie na odzyskiwaniu podmiotowości akademika i pracownika. Jak zauważa Harry Cleaver (1993), w swoich dwóch końcowych tezach o powszechnym kryzysie kapitalizmu, idea odzyskiwania podmiotowości za pośrednictwem praktyki radykalnej demokracji jest wyzwalaniem ludzkości od przymusowych praw konkurencji i rynku. Dla Cleavera tworzenie rewolucyjnej podmiotowości jest splecione z potrzebą rozwinięcia „polityk sojuszu przeciwko kapitałowi [...] nie tylko w celu przyspieszenia międzysektorowej cyrkulacji walk klasy [robotniczej - K.Sz.], ale również uczynienie tego w taki sposób, by zbudować postkapitalistyczną politykę różnicy pozbawionej antagonizmu". W tym kontekście idea akademika jako pracownika, pracującego, by znieść swoja pracę, jest w znacznie większym stopniu kluczowa, niż idea akademika jako sfetyszyzowanego nośnika specyficznych umiejętności, praktyk oraz wiedzy.

Rozpatrując stosunek zawiązany między pracą akademicką a masowa intelektualnością, niniejszy artykuł dokonuje czterech posunięć. Po pierwsze, podejmuje kwestię mechanizmów, za pośrednictwem których autonomia akademicka staje się coraz bardziej wyalienowana wewnątrz-i-przeciwko Uniwersytetu. Po drugie, odnosi tę alienację do kwestii przystosowania Uniwersytetu do formy stowarzyszenia kapitałów. Po trzecie, zadaje pytanie o sposób, w jaki można rozumieć pracę akademicką w kategoriach konkretnych i abstrakcyjnych, a następnie, jak można ja znieść w ramach walk społecznych na rzecz podmiotowości, która przeciwstawia się wytwarzaniu i akumulowaniu wartości. Po czwarte, w artykule postaramy się odpowiedzieć, czy możliwe jest wyzwolenie pracy akademickiej jako formy masowej intelektualności, którą można wykorzystać wewnątrz i w rozciagłości całego społeczeństwa. W tym miejscu uwypuklony zostanie potencjał dla kooperatywnych alternatyw opartych na solidarności, dzięki któremu łączą się one z radykalnymi, społecznymi i demokratycznymi projektami odmowy.

\section{Zwinięcie autonomii akademickiej}

Stephen Ball (2012) wymienia trzy etapy neoliberalizmu. Pierwszy z nich stanowi faza proto, odnosząca się do intelektualnej genezy i dojrzewania projektu neoliberalnego. Idzie tu o kulturowy atak na codzienną rzeczywistość tego, co publiczne oraz Państwa, oraz moment, 
w którym położono podstawy pod budowanie konsensu wokół wartości rynkowych w definiowaniu mechanizmów wytwarzania życia codziennego. W fazie tej umocowano rynek, stawiając go w roli nadrzędnego społecznego arbitra. Stworzono również zestaw przestrzeni znajdujących się wewnątrz-i-przeciwko, dzięki którym Państwo może zostać przekształcone w sposób mogący dostarczać struktury ustawodawczej rozwijającej urynkowienie. Wszystko to staje się pewną doktryną, czy, mówiąc inaczej, nową normalnością.

Drugim etapem jest qwiniecie (rollback), w trakcie którego niszczone jest życie społeczne, uprzednio doświadczane jako życie publiczne. Jak choćby w ramach powojennego keynesowskiego konsensusu, który obejmował darmowe świadczenie opieki zdrowotnej, edukacji oraz usług społecznych (Cumbers 2012). W rezultacie tego rodzaju usługi zostały ogrodzone, poddane finansjeryzacji i urynkowieniu (Deem i in. 2007; McGettigan 2014). Na tym etapie zachodzi wyraźne wzajemne oddziaływanie między doktrynalnym, intelektualnym zapleczem neoliberalizmu a podkopywaniem Państwa i świadczonych przez nie usług publicznych, które ujmuje się teraz jako niewydajne (Willets 2013). Wiąże się to również z kolejnym, trzecim etapem, to znaczy rozwinieciem (rollout) nowej neoliberalnej normalności. Ten ostatni etap obejmuje polityki publiczne, umożliwiające zarówno prywatyzację przestrzeni publicznych, jak również powstawanie nowych stowarzyszeń korporacji czy kapitałów, które są w stanie wydobywać czy akumulować wartość (Deem i in. 2008; Newfield 2013). Otwiera się im również dostęp do dóbr publicznych, w rodzaju emerytur, służby zdrowia czy danych publicznych (Willetts 2014).

Na przykład, w brytyjskim szkolnictwie wyższym te trzy powiązane ze sobą wzajemnie etapy neoliberalizmu wciąż odgrywają swoją rolę, zresztą w niezwykle amorficzny sposób. Mieliśmy jednak do czynienia z ograniczonym, zaledwie intelektualnym projektem dotyczącym tego, na czym powinno polegać szkolnictwo wyższe, czy też z ideą tego, do czego może służyć Uniwersytet. Wszystko to opierało się na ministerialnych broszurach, w rodzaju Robbins Revisited (Willetts 2013), czy analizach rządowego raportu o szkolnictwie wyższym (Higher Education White Paper), które ostatecznie nigdy nie stały się ustawą (McGettigan 2013). Wyrastało to również z wypowiedzi mających na celu powiązanie aktywności Uniwersytetu ze wzrostem gospodarczym (Snowden 2013), poprzez partnerstwa z, dajmy na to, kapitałem finansowym (Willets 2014). Swoją rolę odegrały również analizy roli prywatnych finansów i globalnych dostawców, w rodzaju firmy Pearson Education, w zakresie prywatnej ekspansji wewnątrz szkolnictwa wyższego (Morgan 2013). Willetts (2013) opracował powiązania między danymi, pedagogiką a konsumeryzmem, mając na celu zorganizowanie życia edukacyjnego dla rynku. Kluczowym napędem tego procesu jest udostępnianie informacji dotyczących kształcenia studentom i ich rodzicom, przy ich jednoczesnej prezentacji jako dających się ująć ilościowo działaniach, co ma sprawić, by rodðৃiny były w stanie podejmować decyzje dotyczące kursów (Willetts 2013, 44). Co więcej, twierdzi on, że finansowanie zakorzenione w studenckim 
czesnym pozwoli na zagregowanie tych wyborów. Rezultatem ma być rynek szkolnictwa wyższego, który rzeczywiście będzie wpływał na kształcenie (Willetts 2013, 47).

Tego rodzaju kwantyfikacja praktyk akademickich podtrzymywana jest również przez prawodawstwo wtórne skupione na: kredytach studenckich oraz finansowaniu uniwersytetów; wykorzystywaniu kapitału finansowego oraz rynków papierów wartościowych w ramach długu instytucjonalnego czy refinansowaniu instytucji; wykorzystywaniu progów liczebności studentów przy finansowaniu podstawowej i uzupełniającej liczby studentów oraz deregulowaniu w celu katalizowania konkurencji, jak również przy monetaryzacji studenckich ksiag pożyczkowych (Institute for Fiscal Studies [IFS] 2014). W związku z czym, by móc konkurować, poszczególne uniwersytety zmuszone są do uwzględnienia szeregu strategii mających na celu restrukturyzację. Obejmują one między innymi uzyskiwanie dofinansowania poprzez wejście na rynek papierów wartościowych (McGettigan 2013) oraz rebranding przy jednoczesnym korzystaniu z projektów online, w rodzaju Masowych Otwartych Kursów Online (MOOC). Koncentrują się również na podkopywaniu praw pracowniczych poprzez upowszechnianie kontraktów typu ,zero-godzin”, prekaryzację czy outsourcing pracy (CASA 2014; University of Leeds Postgraduates for Fair Pay [PG4FP] 2014; 3cosas 2014). Ostatni zestaw czynników koncentruje się na przedsiębiorczości i społecznej działalności gospodarczej oraz angażowania się w partnerstwa handlowe z wydawcami czy firmami technologicznymi (Hall 2013). W tym miejscu etap proto urynkowienia szkolnictwa wyższego napotyka zwiniecie państwowego finansowania i regulacji oraz rozwinięcie szans dla urynkowienia oraz akumulacji w ramach naznaczonych konfliktami przestrzeni. Nie pozostawia to osobom zatrudnionym na uniwersytecie żadnych innych możliwości poza koniecznością nadania sensu coraz bardziej kwestionowanemu kontekstowi edukacyjnemu, stanowiącemu coraz istotniejsze źródło ich własnej alienacji (Brook 2009; Constanti i Gibbs 2004; McGinn 2012).

Kluczowym elementem w procesie alienacji uchwytnej i konkretnej rzeczywistości pracy akademickiej są transnarodowe sieci aktywistów tworzące geografię neoliberalizmu (Ball 2012; Robinson 2004). Sieci te obejmuja naukowców i think tanki, ustawodawców i administratorów, kapitał finansowy oraz kapitał typu venture czy private-equity, wydawców edukacyjnych czy filantropów. Ich cel stanowi regulowanie państwa i instytucji, którym nadaje ono strukturę, w tym wypadku uniwersytetów, w celu podporządkowania ich rynkowi, przedsiębiorczości czy zyskowi. Istotne w tym wypadku jest to, że etapy proto, zwijania i rozwijania sa w coraz większym stopniu uruchamiane wspólnie, w czasie rzeczywistym, w sieciach, podporządkowujących pojedyncze uniwersytety stowarzyszeniach kapitałów (Marks 1982), w wyniku czego przestrzeń manewru pojedynczych instytucji zostaje ograniczona w taki sposób, że w obliczu coraz bardziej kurczących się zasobów zostają one zmuszone do przekształcenia się ukierunkowanego na konkurencyjność. 
Trwający obecnie proces przekształcania oddziałuje na codzienne wykonywanie pracy edukacyjnej czy pedagogicznej przez akademików i studentów, transformując: akademickie formy produkcji, wymiany i konsumpcji; akademicki stosunek do przyrody i środowiska; społeczne stosunki między akademikami, menadżerami i studentami; akademickie rozumienia świata; akademickie procesy pracy; uniwersyteckie struktury rządzenia; oraz to, w jaki sposób uniwersytet przyczynia się do społecznej reprodukcji (za: Harvey 2010). Wobec tego akademicy moga zadać sobie następujące pytania:

1) W jaki sposób uniwersyteccy menadżerowie, kadra i studenci wytwarzają, wymieniaja i konsumują towary, wiedzę i wartości? Jaką rolę w tych procesach odgrywa finansjeryzacja czy rynek i kto na nich korzysta?

2) Jaki jest stosunek uniwersytetu do przyrody i środowiska? Jaki jest wpływ czynności wytwórczych uniwersytetu na środowisko, w tym również wzmacnianie przezeń poglądu, że wzrost gospodarczy jest jedyną możliwą opcją?

3) Jakie znaczenie dla społecznych stosunków między ludźmi (w tym stosunków między kadra, między akademikami a studentami, między menadżerami i związkami zawodowymi, między pracą akademicką a tym, co publiczne) ma produkcja i reprodukcja uniwersytetu jako przestrzeni urynkowionej i konkurencyjnej?

4) Co oznacza produkcja i reprodukcja uniwersytetu dla naszych mentalnych sposobów przedstawiania świata? Co oznacza wykształcenie wyższe w kontekście utowarowionej wiedzy czy wzrostu gospodarczego, a co - w kontekście kooperacyjnych, społecznych rozwiązań czy też rozwoju i upowszechniania wiedzy w obszarze społeczeństwa jako masowej intelektualności?

5) W jaki sposób uniwersytet jako przedsięwzięcie konkurencyjne staje się miejscem, w którym występuja i są odtwarzane tymczasowe i prekarne procesy pracy, zarówno pośród kadry akademickiej, jak i studentów? Co dla autonomii pracy akademickiej oznacza odbywający się w obrębie uniwersytetu zwrot przedsiębiorczy?

6) W jaki sposób urynkowiony uniwersytet wpływa na nasze rozumienie demokratycznego i społecznego sposobu rządzenia? Jakie formy poznawczego dysonansu oddziałuja na role kadry akademickiej w kontekście nadawania sensu temu przekształceniu, narzucanemu poprzez etapy proto/ zwijania/ rozwijania neoliberalnego uniwersytetu?

Kadrze akademickiej, która chciałaby odpowiedzieć na te pytania, należy podsunąć Marksowską odpowiedź Feuerbachowi, który stwierdził, że „[ż]ycie społeczne jest z istoty swej praktyczne. Wszelkie misteria sprowadzające teorię na manowce mistycyzmu znajduja swe racjonalne rozwiązanie w praktyce ludzkiej i w pojmowaniu tej praktyki." (Marks 1979, X). Rozważenia domaga się krytyczny projekt pedagogiczny, który nie waloryzuje określonych 
praktyk przedsiębiorczych, sprawiających, że pojedynczy akademik/student staje się ustępliwy czy zatrudnialny (employable) czy też wykwalifikowany jako pracownik-towar na rynku. Tego rodzaju projekt zakorzeniony jest w usytuowanej, demokratycznej aktywności wytwórczej, zwierciadlanie przeciwnej wobec kooptacji pracy akademickiej przez współczesne etapy proto/zwijania/rozwijania neoliberalnego uniwersytetu. Co więcej, tworzy krytykę, transnarodowej, długotrwałej, wdrażanej pedagogicznie, kontroli sprawowanej przez stowarzyszenia kapitałów nad materialną rzeczywistością życia codziennego (Cleaver 1993, 2012).

\section{Produkcja akademicka wewnątrz stowarzyszeń kapitałów}

Idea subsumcji pracy akademickiej wewnątrz obiegów kapitału staje się coraz bardziej istotna w świetle Marksowskiej (1982;1977) koncentracji na stowarzyszeniowej fazie kapitału, w której rozwój dokonuje się na obszarze globalnym, a kapitał handlowy, pieniężny i produkcyjny wchodza ze sobą we wzajemne stosunki. Uniwersytet nie jest przekierowywany w stronę rynkowa po prostu przez swoich wicekanclerzy, ale raczej przez stowarzyszenia ustawodawców, właścicieli funduszy inwestycyjnych, agencje ratingowe, firmy technologiczne i wydawców, a pośrednio również przez płacących czesne studentów, którzy razem tworzą zdeterytorializowaną sieć (Ball 2012; Deem i in. 2007; McGettigan 2013; 2014; Robinson 2004). Wydobycie wartości dodatkowej z produkcji przez kapitał handlowy stanowi tu główne źródło zysku, a w ramach produkcji edukacyjnej wykorzystuje się w tym celu kapitał finansowy i kredyt, by zwiększyć wskaźnik zapasu poszczególnych towarów edukacyjnych czy usług-jakotowarów (Gartner 2013; Lipman 2009). Osiagane jest to poprzez obywająca się online produkcję i cyrkulację zasobów związanych z programami studiów oraz poprzez konkurencyjne naciski ze strony otwartej edukacji, MOOC'ów, jak również poprzez pomiary edukacyjne (Ravitch 2012; Thorburn 2012). Zarządzanie i sprzedaż studenckiego zadłużenia, a także korporacyjne zaangażowanie zarówno w finansowanie centrów badawczych oraz wymianę wiedzy, jak i w outsourcing fizycznej oraz technicznej infrastruktury, stanowią uzupełnienie tych strategii.

W związku z tym, w celu stworzenia alternatywnej, konkretnej rzeczywistości warto przemyśleć sposób, w jaki kapitał finansowy, handlowy czy kredytowy wpływają na wewnętrzne funkcjonowanie edukacji, w szczególności w czasach, gdy uniwersytety ulegaja wewnętrznym przekształceniom, stając się odpowiednikami spółek akcyjnych, poddanych przymusowej logice konkurencji o granty badawcze i studentów. Jaki jest wpływ przymusowej roli pieniądza, gdy zostaje wpleciona w praktyki edukacyjne? Do jakiego stopnia ten proces wymusza urzeczowienie studenta, przedsiębiorczość akademicką czy zastosowanie określonych technologii? W jaki sposób upolitycznienie tych ról odnosi się do procesu 
reprodukcji kapitału? Rynek, określony przez byty korporacyjne działające w charakterze kapitalistów handlowych, zostaje oddzielony od rzeczywistości produkcji edukacyjnej jako aktywności społecznej, ulegają w ten sposób przekształceniu w narzędzie sprzyjające indywidualnej produkcji i konsumpcji usług i produktów edukacyjnych. Wobec tego, studenci/kadra akademicka zostają przekształceni nie tyle w społeczne podmioty uczenia się/kształcenia, co w indywidualnych przedsiębiorców zdolnych do dostępu/wytwarzania usług i produktów edukacyjnych na globalnym rynku.

W tym procesie komercjalizowania edukacji pojawiają się jednak napięcia płynące z coraz większego ograniczenia przestrzeni dostępnych dla aktywności kapitału produkcyjnego, odróżnianego w tym miejscu od kapitału rentierskiego i przynoszącego procent (Marks 1982). W rezultacie mamy do czynienia ze wzrostem wpływu aktywności kapitału typu venture czy inwestycji ze strony funduszy typu private-equity na przekształcanie uniwersytetu i technologiczne innowacje, po części dlatego, że wiążą się one z wyższymi poziomami krótkookresowej zyskowności. Ten nacisk na utowarowienie usług i danych, zamiast skupienia na zdolnościach wytwórczych, rozpuszcza wcześniejsze formy produkcji akademickiej. Ponieważ kapitał pieniężny i jego właściwości określają uniwersytet, pojawia się globalna presja na jego reformowanie (Gartner 2013; PA Consulting 2014) lub rewolucjonizowanie jako formy organizacyjnej (społecznej, kulturowej lub handlowo/finansowej) stworzonej dla akumulacji kapitału (McGettigan 2014). Harvey (2013) określa to jako „czynnik rozpuszczający”, który ma również charakter koniunkturalny w ramach rozwoju rynku światowego. Dominację kapitału handlowego nad produkcją można zaobserwować na uniwersytecie choćby w coraz bardziej prekarnych warunkach pracy poddanych outsourcingowi pracowników czy w ramach deptania akademickich praw pracowniczych. Zwiększa się ona również za sprawą organizacyjnego rozwoju i wdrażania metodologii zarządzania w rodzaju odchudzonej produkcji, PRINCE2, czy programów w rodzaju Managing Successful Programmes. Jednym z jej efektów jest upowszechnienie się umów typu „zero godzin”, prekarnego zatrudnienia kadry, doktorantów lub młodych pracowników, którym płaci się od godziny pracy. Nacisk kładzie się tu na tworzenie i utrzymywanie nadwyżki ludności/pracy, mogącej podtrzymać globalny podział pracy i przyczyniać się do podkopywania solidarności.

Podążając za Marksem (1982), musimy stwierdzić jednak, że może to również skłaniać kadrę akademicką do ponownego skupienia się na akcie produkcji, a nie na obiegach pieniężnych czy kapitale handlowym, jako rzeczywiście rewolucyjnej aktywności społecznej. Kampanie w rodzaju 3cosas (2014), PG4FP (2014), czy Australian anti-Casualisation (CASA 2014) stawiaja istotne pytania o to, gdzie w akademii znajduje się dziś władza. Tego rodzaju akcje wskazuja na napięcia zachodzace między kapitałem finansowym, handlowym i produkcyjnym, oraz na to, w jaki sposób tego rodzaju napięcia oddziałują na pojedynczych wytwórców i konsumentów produktów edukacyjnych. Zmuszają nas również do uznania 
istnienia różnych warstw składających się na akademicką siłę roboczą. Jeśli chodzi o tę ostatnią kwestię, akademicka siła robocza składa się z profesorów zwyczajnych, profesorów nadzwyczajnych, adiunktów, tymczasowych wykładowców, asystentów i tak dalej. Wszyscy oni zatrudnieni sa w ramach całej palety stałych bądź tymczasowych umów. Rożne poziomy władzy funkcjonujące pośród tych warstw ułatwiają możliwość dyscyplinowania. Co więcej, dzięki mechanizmom w rodzaju płacy powiązanej z wydajnościa możliwe jest tworzenie podziałów między akademikami hamujących solidarność niezbędną do zniesienia pracy akademickiej jako takiej.

Tego rodzaju stratyfikacja zwiększa się tam, gdzie korporacje edukacyjne kontroluja większą część wytworzonej wartości dodatkowej. W takich sytuacjach mogą one dyscyplinować i dzielić produkcję w oparciu o arbitraż pracy oraz odmowę negocjacji ze zorganizowaną pracą akademicka. Gdy zatrudnienie staje się bardziej niepewne, wśród pełniących różne role zindywidualizowanych i oddzielonych wytwórców edukacyjnych neguje się solidarność i kooperację. Pojawiają się wtedy hiperwyzysk oraz proletaryzacja. W konsekwencji dominacja kapitału handlowego i finansowego prowadzi do obniżenia cen w sferze produkcji i przyczynia się do przekształcenia form organizacyjnych poprzez parcie na efektywność i technologiczną innowację (Marks 1986).

Analiza Andrew McGettigana (2014) dotycząca przekształcenia edukacji przez fundusze hedgingowe $\mathrm{i}$ inwestycyjne, firmy technologiczne, agencje ratingowe, wydawców, think tanki i tak dalej, ukazuje sposób, w jaki wytworzony wewnątrz uniwersytetu kapital cyrkuluje i jest akumulowany na obszarze globalnym:

Ponieważ uniwersytety odzwierciedlają coraz bardziej nierówny charakter angielskiego społeczeństwa, oferują raczej dobro pozycyjne niż rynkowe: ich rola w rozszerzaniu społecznej równości czy też zmniejszaniu utrwalonego niekorzystnego położenia zostanie oczerniona przez merytokratyczną grę polegającą na poszukiwaniu „talentów” oraz zapewnianiu, że każdy z nich zostanie umieszczony we właściwej przegródce. Jednak możliwość porzucenia nawet tak minimalnego zaangażowania na rzecz sprawiedliwego dostępu osiaga swój punkt krytyczny, gdy przejście od dobroczynności do nastawienia na zysk ułatwiane zostaje przez rząd. Jest to coś tak nowatorskiego, że nie mamy nawet słowa na określenia tego procesu („prywatyzacja” go nie uchwytuje, ponieważ dobroczynność sama w sobie jest już prywatna). Mamy jednakże pewien precedens. W 2012 roku [brytyjski] College of Law został sprzedany funduszowi Montagu Private Equity za 200 milionów funtów. Dokument dotyczący strategii eksportowej zachęca uniwersytety do rozważenia tego rodzaju opcji, jeśli chcą korzystać z nowych okazji umożliwianych przez rewolucję cyfrowa, utwierdzająca edukacje w statusie usługi świadczonej na sprzedaż. Rozumie się samo przez się, że ten proces oraz powiązana $\mathrm{z}$ nim finansjeryzacja połączona z ogólnym schematem dłużnym (generalised loan scheme) będą się wzajemnie wzmacniać. Chociaż obszar ustawodawczy 
jest tymczasowo ustalony, piłka znajduje się zdecydowanie po stronie poszczególnych instytucji: istnieje naprawdę niewiele zabezpieczeń przeciwko ambicji aroganckich wicekanclerzy podsycanych nowymi możliwościami finansowymi.

Co najważniejsze, subsumcja uniwersytetów pod mechanikę kapitalistycznej reprodukcji i finansjeryzacji wymaga rynku. Stosuje się to zarówno do wicekanclerzy działających jak dyrektorzy generalni czy początkujący przywódcy biznesowi, jak i do prywatnych dostawców usług edukacyjnych, potrzebujących określonych wartości użytkowych w rodzaju treści programów nauczania, danych, partnerstw wymiany wiedzy, wyników badań w postaci produktów, infrastruktury technicznej itd., w określonej ilości, która może zostać zakupiona i zaprzęgnięta do pracy. Co najistotniejsze, praca ta musi wytwarzać wartość dodatkową i zysk. $\mathrm{Z}$ tego powodu potrzebuje rynku, a jeśli nie istnieje on w danym momencie, musi zostać stworzony. Potrzeba rynku jest również rozszerzana na potencjalnych studentów, którzy zaciagają dług i są zachęcani do kupna towarów lub usług-jako-towarów w charakterze dóbr pozycyjnych. Materialne okoliczności produkcji, kupno i cyrkulacja towarów edukacyjnych posiadaja zatem kluczowe znaczenie i katalizuja politykę, przekształcając ją w narzędzie transformacji pracy intelektualnej i akademickiej.

\section{Ponowne przemyślenie konkretnej/abstrakcyjnej pracy akademickiej}

Jednym z kluczowych problemów dla pracowników akademickich jest to, że ze względu na strukturalne zdominowanie ich pracy przez towarowych kapitalistów muszą oni rywalizować ze sobą o miejsca na rynku. Sprawia to, że stają się podatni na kryzysy związane z: handlem opcjami; dostępem do środków produkcji; nadprodukcja; nasyceniem rynku; niedostępnością kredytu; czy mówiąc ogólniej, społecznym dostępem do długu. Prowadzi to zarówno do przekształcenia instytucji, jak również do zredukowania momentów solidarności pracy akademickiej. W związku z tym rzeczywiste oddziaływanie kapitału finansowego na tworzenie rynkowego szkolnictwa wyższego w oparciu o katalizowanie nowych systemów produkcji, rozwoju organizacyjnego czy innowacji technologicznej wystawia uniwersytety na ryzyko. Co więcej, czyni to również w odniesieniu do pracowników akademickich, ponieważ osławiona uniwersytecka autonomia instytucjonalna wyabstrahowuje Uniwersytet $z$ pojęcia dobra publicznego i dystansuje go od jakiegokolwiek uspołecznionego celu czy znaczenia (Thorburn 2012). Jako że rządowa polityka opiera się na konkurencji (Willetts 2014), publicznym wsparciu dla innowacji w rodzaju MOOC (Willets 2013), inwestycji typu venture capital w start-up'y z obszaru technologii edukacyjnych (Gartner 2013) czy reorganizacji i przekształcaniu Uniwersytetu, trudno oddzielić ją od rynkotwórczego pędu.

Jednym z rezultatów tego pędu jest potrzeba utowarowienia zarówno pedagogii, jak $i$ stosunków akademickich. Za Marksem (1977) można uznać, że rola wykształcenia w 
tworzeniu i wymianie towarów jest kluczowa dla procesów, które wiążą i wzmacniaja finansjeryzację i urynkowienie, ponieważ towar jest społeczną formą, w odniesieniu do której może być rozważany każdy kapitał edukacyjny. Globalny obieg towarów edukacyjnych jest formą ruchu wspólną wszystkim edukacyjnym kapitałom. Jest społeczny jedynie pod tym względem, pod jakim tworzy całościowy kapitał społeczny klasy kapitalistycznej, przekształcając edukację w skali transnarodowej. Co więcej, ruch poszczególnych kapitałów edukacyjnych uwarunkowany jest przez jego stosunek z innymi kapitałami edukacyjnymi - czy będą to uniwersytety publiczne, czy prywatne, nastawione na zysk uczelnie. Oto materialny stosunek podkreślany przez kategorie towaru, konkurencji, wydobywania wartości dodatkowej, akumulacji, finansjeryzacji oraz stopy zysku.

Ten proces utowarowienia zachodzący w szkolnictwie wyższym katalizowany jest również przez formację wartości oraz towarzyszące temu zdominowanie pracy akademickiej przez czas. Jak pisze Postone (1996, 191):

\footnotetext{
„Jako kategoria całokształtu, społecznie niezbędny czas pracy wyraża quasi-obiektywny społeczny przymus, z którym konfrontowani są wytwórcy. Jest to czasowy wymiar abstrakcyjnej dominacji, charakteryzującej struktury wyalienowanych stosunków społecznych w kapitalizmie. Społeczny całokształt ukonstytuowany przez pracę, jako obiektywne ogólne zapośredniczenie, posiada charakter czasowy, zgodnie z którym čas staje sie praymusem".
}

W rezultacie Uniwersytet wplątany w sieci rynku staje się źródłem wartości, jak również wyszukuje wartość, którą mógłby czerpać z tych nowych rynków. Wyczerpanie powodowane przez ilość czasu, jaki średnio akademicka siła robocza musi poświęcać na wytwarzanie, cyrkulowanie czy wymianę towarów prowadzi do zniszczenia towarzyskości i solidarności powszechnej wcześniej wśród akademików, którzy muszą teraz ze sobą konkurować. Dlatego społecznie niezbędny czas produkcji akademickiej coraz bardziej dominuje w życiu naukowca i studenta. W przypadku akademika dominacja ta pogarsza się, gdy Uniwersytet zostaje podporządkowany akumulacji wartości, gdyż akademickie środki produkcji zostają w konieczny sposób zrewolucjonizowane wskutek zmiany technologicznej i organizacyjnej. Prowadzi to do przyspieszenia pracy akademickiej, pomiarów jej wpływu, technologii produkcji „zawsze na czas", zarządzania wydajnością czy też odchudzonej produkcji, wykorzystania analityki kształcenia czy wydobywania danych i tak dalej. Ma to umożliwić mierzenie i porównywanie produkcyjności czy wydajności akademików za pośrednictwem społecznie niezbędnego czasu pracy, który określa, jaka ta wydajność być powinna. Na konkurencyjnych, transnarodowych rynkach edukacyjnych prawa pracowników akademickich zostaja zagrożone przez wyrównujący nacisk społecznie niezbędnego czasu pracy. Co więcej, presja ta zmierza o 
wpływania na potencjał kooperacji między naukowcami w obrębie instytucji i w całym sektorze.

Tym, czego brakuje w dzisiejszych dyskusjach dotyczących poziomu czesnego, studentów jako konsumentów/klientów, płac wicekanclerzy oraz zarządu, zderegulowanych rynków i kontroli nad liczbą studentów, alokacją przychodów z badań itp. jest raczej sensowna dyskusja o wartości pracy akademickiej jako społecznej pracy/działaniu raczej niż urzeczowionej wartości wymiennej (Harvey 2010; Marks 1968; Postone 1996; Wendling 2009). Czym jest jej wartość wymienna jako pracy/działania dla społeczeństwa, w odróżnieniu od jej ceny jako towaru/akademickiej siły roboczej? W coraz większym stopniu praca akademicka zostaje wyabstrahowana dla celów wymiany i podporządkowana prawom konkurencji. Jak zauważa Wendling $(2009,52)$ jest to dyscyplinarna „społeczna tyrania wartości wymiennej, tak wszechstronna, że określa to, w jaki sposób tworzy się rzeczy, a nawet to, jakie rzeczy są tworzone [...]. Kapitalizm nie dba o to, czy wytwarza masę dóbr do użytku; dba wyłącznie o wytwarzanie zysku”. To właśnie w kontekście tej tyranii można z pożytkiem dyskutować i ponownie oceniać wartość pracy akademickiej wrazz kosztem jej siły roboczej, wytworami kształcenia/badania, które tworzy, oraz ze stosunkami, które umożliwia i utrzymuje. Na mocy globalnego arbitrażu pracy, outsourcingu oraz prekarnego zatrudnienia ustanawia się dziś alienację pracy akademickiej - poprzez grodzenie i utowarowienie jej wytworów i stosunków. To skupienie uwagi na wymianie wspierane jest następnie przez abstrakcyjne imperatywy kulturowe w rodzaju idei studenta-jako-konsumenta, wykorzystanie rankingów czy wskaźników wpływu oraz rozwój wymiany wiedzy i praw własności intelektualnej (Lipman 2009; Neary 2012).

W związku z tym analizowanie wzajemnego oddziaływania między abstrakcją a jej konkretną realizacją ma fundamentalne znaczenie dla rozumienia formowania i kooptacji pracy akademickiej. Z tej perspektywy możemy dostrzec przepływ między tym, co konkretne a tym, co abstrakcyjne, dokonujący się w taki sposób, że każdy z tych elementów wyłania się z drugiego i wzajemnie wzmacnia. Prowadzi to Postone’a $(1980,108)$ do następującego stwierdzenia: „należy wobec tego znaleźć podejście pozwalające na rozróżnienie między tym, czym jest nowoczesny kapitalizm a sposobem, w jaki się jawi, czyli między istotą a pozorem. Pojęcie »tego, co nowoczesne« nie pozwala na takie rozróżnienie. Te rozważania prowadzą nas do Marksowskiego pojęcia fetyszu, którego strategicznym celem miało być zapewnienie teorii społecznej i historycznej wiedzę ugruntowaną w różnicy między istotą kapitalistycznych stosunków społecznych a formą, którą przybierały”.

Decydujące jest tutaj poszukiwanie środków dekodowania tego, w jaki sposób społecznie wytwarzane stosunki edukacyjnej produkcji oraz edukacyjnych towarów zostaja uzewnętrznione i przybieraja formę fetyszy. Co więcej, stosunki i formy są zarazem abstrakcyjne, jak i konkretne, a każde $\mathrm{z}$ nich przenika produkcję i reprodukcję drugiego. 
Przejawia się to na powierzchni spoleczeństwa w postaci zestawu stosunków zapośredniczonych i wyabstrahowanych przez pieniądz (koszt dyplomu zredukowany jest do czesnego i służy jako reprezentacja wartości) oraz przez prawo (w kategoriach wymogów dla opublikowanych danych czy dostępu do/kontroli rynku itd.). Dla wielu akademików praca abstrakcyjna zakorzeniona w wartości wymiennej wydaje się mniej znacząca czy rzeczywista niż konkretna forma pracy akademickiej wywodząca się z samokrytycznej pracy badawczej (Harvey 2013; Postone 1980). Jednakże w obrębie globalnego rynku edukacyjnego oraz wobec strukturującej roli pieniądza trudne staje się wyjście poza alienację zarówno konkretnej, jak i abstrakcyjnej pracy akademickiej, ponieważ żadna $z$ nich nie może zostać właściwie zdekodowana. Postone $(1980,109)$ twierdzi w tym kontekście:

\begin{abstract}
Jednym $z$ aspektów fetyszu jest zatem to, że kapitalistyczne stosunki społecznie nie jawią się jako takie oraz, co więcej, przedstawiają się antynomicznie jako opozycja tego, co abstrakcyjne i tego, co konkretne. Co więcej, ponieważ obie strony antynomii sa urzeczowione, każda jawi się jako coś quasi-naturalnego: wymiar abstrakcyjny jawi się w formie „obiektywnych”, „naturalnych” praw; a wymiar konkretny jako czysta „rzeczowa” natura. Struktura wyalienowanych stosunków społecznych, która określa kapitalizm, posiada formę quasi-naturalnej antynomii, w ramach której to, co społeczne i to, co historyczne nie przejawiają się.
\end{abstract}

Oto dialektyczna relacja między tym, co abstrakcyjne a tym, co konkretne, która jest zarówno historyczna, jak i materialna, oraz która subsumuje życie akademickie jako pracę pod obszar wytwarzania wartości i akumulacji. Bez analizy sposobów, na mocy których qarówno konkretna, jak $i$ abstrakcyjna praca akademicka manifestuje się na gruncie kapitalistycznych stosunków społecznych oraz wytwarza wartość, nie ma możliwości przezwyciężenia kryzysów. Postone (1980) wysuwa kluczowy argument odnośnie stosunku między konkretną, wytwórczą manifestacja kapitału, poprzez jego stosunek z przemysłem i technologia jako formą naturalnego trudu (work) czy pracy (labour), oraz kryzysem. Wynika stąd idea, że:

to, co konkretne jest „naturalne”, oraz nieustanne przedstawianie tego, co społecznie „naturalne” w taki sposób, że postrzega się je w kategoriach biologicznych. To właśnie hipostazowanie tego, co konkretne i utożsamienie kapitału z tym, co manifestuje się jako abstrakcyjne, czyni tę ideologię tak funkcjonalną dla rozwoju przemysłowego kapitalizmu w kryzysie. [...] Utożsamienie kapitału z tym, co manifestuje się jako abstrakcyjne pokrywa się częściowo z utożsamieniem go z rynkiem. Atak na państwo liberalne, jako abstrakcyjne, może przyczynić się do dalszego rozwoju państwa interwencjonistycznego jako tego, co konkretne. Taka forma „antykapitalizmu” wydaje się z utęsknieniem spoglądać wstecz. Ponieważ jednak jest ona wyrazem fetysza kapitału, w rzeczywistości jej impet zwraca się naprzód. W sytuacji strukturalnego 
kryzysu stanowi wsparcie dla kapitalizmu w ramach jego przejścia do formy quasipaństwowej (Postone 1980, 111).

W momentach kryzysu błędem jest poszukiwanie rekompensaty w technokratycznym określaniu, zmianie organizacyjnej czy w kategorii abstrakcyjnego rozumu. Równie alienujące jest poszukiwanie naturalnych rozwiązań w formie pracy konkretnej czy wartości użytkowej generowanej przez trud (work), ponieważ obie ścieżki sa historycznie i materialnie „bezsilne w obliczu kapitału”, jak również nie oferuja żadnych wskazówek odnośnie tego, jak zmierzać w stronę postkapitalizmu (Postone 1980,115). Oto skrajne napięcie, na które skazana jest praca akademicka, najczęściej przybierające ukryta postać idei „dobra publicznego” oraz autonomii (Cumbers 2012; Thorburn 2012), powiązanych z pozarynkową wartością użytkowa. Jako że praca akademicka w swoich uwarstwionych formach nakłada się na transnarodowe obiegi towarowego kapitalizmu, dwoistość jej abstrakcyjnej i konkretnej istoty urzeczywistniana jest wewnątrz-i-przeciwko kategoriom, które ją definiuja, to znaczy towaru, pieniądza, siły roboczej oraz wartości (Jappe 2014). Zarówno abstrakcyjna, jak i konkretna praca oraz jej manifestacje w użytku i wymianie zakorzenione są w produkcji, cyrkulacji oraz akumulacji wartości, jak również w pędzie kapitału do samopomnażania.

\section{Wartość i akademicka alienacja}

Potrzebujemy zatem środków umożliwiających krytykowanie alienacji narzuconej przez kapitalistyczne warunki pracy (work) i wyłaniającej się z tych warunków, w ramach ich wzajemnie powiązanych abstrakcyjnych i konkretnych form, jak również poprzez właściwą pracy fetyszyzację technologicznych rozwiązań kryzysów (w ich politycznych, finansowych, społecznych czy środowiskowych przejawach) (Breverman 1998). Powodzenie starań mających na celu przezwyciężenie kryzysów zrodzonych z konkurencji poprzez odnawianie osobistych, społecznych czy transnarodowych wartości, które jako takie zostały ukształtowane wewnątrz dynamiki konkurencji, jest niemożliwe (Cleaver 2012). Nie sposób doprowadzić do społecznej rewolucji życia poprzez rewolucję społecznej (re)produkcji, zakorzenionej w wytwarzaniu wartości i w pracy. Podobnie rzecz ma się z odzyskaniem pracy konkretnej czy wartości użytkowej jako domniemanego antidotum na bolączki abstrakcyjnego świata kapitalistycznego. Jako że naturalny świat jest subsumowany i reprodukowany w ramach ekologii kapitalizmu, ukazuje ona zarówno to, co konkretne, jak i to, co abstrakcyjne, jako coś alienującego.

Jest to o tyle istotne, że praca akademicka okazuje się być w coraz większym stopniu subsumowana pod materialna (strukturalną i systemowa) oraz historyczną niezdolność kapitału do przezwyciężenia ograniczeń w ramach stabilnych, globalnych form akumulacji (Cleaver 1993). Anselm Jappe (2014) twierdzi, że kapitalistyczny sposób produkcji napotyka swoje 
historyczne ograniczenia po części za sprawa technologicznej innowacji, która niszczy organiczny skład kapitału i podkopuje podstawę produkcji wartości oraz stopę zysku. Jednym z kluczowych problemów jest to, że w skali globalnej „bezwzględna ilość wartości, a zatem wartości dodatkowej, zalicza ostre spadki” (Jappe 2014, 7), co narzuca kryzys każdemu społeczeństwu opartemu na produkcji i akumulacji wartości. Wydaje się, że w tej sytuacji opór akademików i studentów może wymagać ponownego skoncentrowania się na kontrhegemonicznym potencjale akademickiej siły roboczej, wiedzy, umiejętności i praktyk na rzecz społecznie użytecznej pracy (work) czy działania, które znajduje się poza systemem wartości kapitału.

Za Marksem (1968) stwierdzamy, że odsłania to zestaw sprzeczności i napięć między użyciem a wymianą w obrębie produkcji i ruchu wartości; w związku z tym należy podjąć w kontekście Uniwersytetu kwestię roli pracy jako twaru. W jaki sposób mamy waloryzować pracę (work), którą wykonuja akademicy? W jaki sposób dodaje ona wartość i komu, oraz jak może zostać uwolniony jej społeczny potencjał? Oznacza to, że akademicy muszą zrozumieć konkretne i abstrakcyjne zapośredniczenie swojej własnej pracy (Postone 1980) w celu uchwycenia mechanizmów, na mocy których praca ta jest wykorzystywana. Oznacza to również, że odsłanianie różnorodności pracy akademickiej może umożliwiać pojawienie się momentów solidarności.

W tym miejscu wracamy do mechanizmów, za pośrednictwem których praca akademicka zostaje poddana kooptacji, po czym zarówno ulega wyabstrahowaniu z obiegów produkcji (w ramach rynku papierów wartościowych czy długu studenckiego) jak $i$ zostaje przekształcona w pracę konkretną w rzeczywistości życia codziennego (w ramach oceniania czy udzielania informacji zwrotnej czy też pisania). Wracamy również do roli pracy akademickiej w reprodukcji społeczeństwa, opartego na produkcji wartości i akumulacji:

Pojawia się rosnąca dysproporcja między postępami w obszarze wytwórczych sił pracy (które niekoniecznie powiązane są z bezpośrednią pracą robotników), z jednej strony, oraz ramą wartości, w obrębie której wyrażane są tego rodzaju postępy (co jest powiązane z tego rodzaju praca), z drugiej. Dysproporcja między akumulacją historycznego czasu a urzeczowieniem czasu pracy bezpośredniej wybrzmiewa jeszcze bardziej, gdy wiedza naukowa jest w coraz większym stopniu materializowana w produkcji [...] rosnąca dysproporcja oddziela warunki umożliwiające produkcję rzeczywistego bogactwa od tych sprzyjających generowaniu wartości. (Postone 1996, 297).

Wymaga to przeanalizowania pracy akademickiej w kategoriach kryzysu tworzenia wartości w obszarze globalnym (Cleaver 1993, 2012; Jappe 2014). Mogłoby to pozwolić kolektywnym organizacjom etatowych i tymczasowych pracowników akademickich na znalezienie momentów umożliwiajacych współdziałanie i solidarność. Nie ma to na celu urzeczowienia pracy akademickiej w jej konkretnych formach czy sposobach użycia, ani też 
ochoczego akceptowania jej subsumcji w obręb obiegów wymiany. Jednakże przekształcenie umiejętności, praktyk oraz wiedzy akademików i studentów, których praca jest jednocześnie konkretna i abstrakcyjna, użyteczna i wykorzystywana dla celów wymiany, zachodzi w czasie, gdy powszechny kryzys kapitalizmu oznacza, że nie da się przywrócić stabilnych form akumulacji (Cleaver 1993). Ten powszechny kryzys (secular crisis) ma charakter transnarodowy, jak również gospodarczy, społeczny i polityczny; posiada również środowiskowe symptomy o charakterze materialnym i historycznym. Być może te transnarodowe, stowarzyszeniowe formy kapitalistycznego rozwoju wskazują na alternatywną możliwość, że praca akademicka mogłaby zostać rozpuszczona wewnątrz i pomimo społeczeństwa, w postaci intelektualności masowej.

\section{Praca akademicka i szansa dla intelektualności masowej}

Twierdzenie, że praca akademicka w coraz większym stopniu zakorzeniona jest w globalnym wyzysku, również związane jest z punktami akademickiej/studenckiej wspólności i solidarności. Tego rodzaju punkty solidarności ukazuja potencjał pracy do bycia społecznie użyteczna, a zatem wyzwoloną w postaci wspólnego bogactwa. Potencjał ten koncentruje się na kolektywnym wyzwoleniu spod dominacji czasu abstrakcyjnego oraz odzyskaniu życia ukierunkowanego na wykonywanie konkretnych zadań (Thompson 1967). Polega również na odrzuceniu, korzystając z kategorii Postone’a (1996, 202), koncepcji czasu, który jest ,jednolity, ciagły, homogeniczny [...] oraz opróżniony z wydarzeń”. W tym miejscu praca użyteczna ujawnia się poprzez zadania i wydarzenia, które reprodukuja społeczeństwo przeciwko-i-poza produkcją wartości. Jest ona formą towarzyskości (sociability), niezachodzącej w obrębie czasu, a raczej nadającej strukturę i określającej ten czas (Postone 1996, 201).

Urzeczywistnianie zdolności akademików i studentów jako badaczy do postrzegania swojej prace jako wspólnej, zmierzającego do kooperatywnego myślenia i działania oraz przezwyciężania tej pracy, prowadzi nas poza troski dotyczące sfetyszyzowanej produkcji i własności pracy akademickiej. Ważne jest w tym procesie odzyskiwanie pojęcia żywej wiedzy czy wyzwolenie intelektu powszechnego jako formy „masowej intelektualności”. Marks (1986, 567) twierdzi, że dynamika kapitalizmu oznacza, iż kapitał wchłonął: „nagromadzenie wiedzy i biegłości, powszechnych sił wytwórczych mózgu społecznego, i dlatego cechy te jawią się pracy jako właściwość kapitału, a ściślej — kapitału trwałego, o ile wstępuje do procesu produkcji jako właściwy środek produkcji."

Techniczna i wykwalifikowana praca uspołecznionego robotnika, działającego w fabrykach, korporacjach czy szkołach, zostaje subsumowana poprzez innowacje i konkurencję wewnątrz maszyn i techniki. „Intelekt powszechny” społeczeństwa zostaje zatem wchłonięty w obręb kapitalistycznych technologii i techniki w celu zredukowania kosztów 
pracy i wzmożenia wydajności. W konsekwencji „praca stanowi już nie tyle część produkcji, ile raczej człowiek uczestniczy w procesie produkcji, jako nadzorca i sterujący.” (Marks 1986, 572). Jednakże, jak stwierdził kolektyw University of Utopia (2014), ponowne przemyślenie intelektu powszechnego może tworzyć punkt wyjścia, w którym:

Jako robotnicy umysłowi odrzucamy sfetyszyzowane pojęcie społeczeństwa wiedzy oraz angażujemy się w kształcenie, uczenie się oraz badanie jedynie w celu odzyskania wiedzy skradzionej robotnikom, którzy wytworzyli ten sposób poznania (tj. obfitość). W społeczeństwie obfitości uniwersytet jako forma instytucjonalna zostaje rozpuszczony i staje się społeczną formą lub wiedzą z poziomu społeczeństwa (tj. intelektem powszechnym). Jedynie na tej podstawie możemy świadomie zmierzyć się z globalnymi niebezpieczeństwami, do których wszyscy musimy się dziś ustosunkować.

Koncentracja na możliwościach wyłaniających się z kooperatywnej pracy oraz działań zakorzenionych w rozkwicie alternatywnych praktyk edukacyjnych wskazuje na rozwój uspołecznionej wiedzy czy „masowej intelektualności” jako bezpośredniej, społecznej siły wytwórczej. Jak stwierdził University of Utopia: „,masowa intelektualność oparta jest na naszej wspólnej zdolności do działania, opartej na naszych potrzebach i zdolnościach oraz na tym, co jest do zrobienia. To, co należy zrobić, wyprowadza działania z poziomu indywidualnego na poziom społeczeństwa."

Dla Paola Virna (2001) tego rodzaju uspołecznienie/towarzyskość (sociability) wykracza poza organizacyjny i technologiczny determinizm, jak również poza fetyszyzację społecznej czy indywidualnej przedsiębiorczości, zamiast tego koncentrując się na „depozycie kompetencji kognitywnych, które nie moga zostać uprzedmiotowione w maszynie”. Z tej perspektywy intelektualność masowa wyłania się z

\footnotetext{
bardziej ogólnych postaw umysłu, które zyskują podstawowy status jako zasoby wytwórcze; są nimi: zdolność języka, dyspozycja do uczenia się, pamięć, potęga abstrakcji oraz relacji, jak również tendencja do samorefleksyjności [która tworzy] nieprzebrany potencjał języka do wykonywania przypadkowych i niepowtarzalnych zdań. Podobnie jak intelekt i pamięć, język jest najbardziej wspólnym i najmniej „wyspecjalizowanym: wyobrażalnym przymiotem. Dobrym przykładem masowej intelektualności jest nie tyle naukowiec, co mówca. Masowa intelektualność nie ma nic wspólnego z nową „arystokracją pracy”; w rzeczywistości jest czymś całkowicie przeciwnym (Virno 2001).
}

Zmagania o intelektualność masową są staraniami na rzecz budowania kontrhegemonicznego stanowiska zakorzenionego w solidarności i współdzieleniu oraz powiązanego ze społecznym i kooperatywnym wykorzystaniem wiedzy, umiejętności oraz praktyk stworzonych poprzez 
pracę (Bologna 2014). Jest to rozmyślnie przeciwstawne utowarowieniu, wymianie, akumulacji i pomnażaniu tej wiedzy, umiejętności oraz praktyk przez transnarodowe elity (Cleaver 2012; Virno 2001). W związku z tym wyzwalanie nauki i technologii wewnątrz-i-przeciwko konkurencyjnej dynamice kapitału jest kluczowe do wykraczania poza wyzysk. Wewnątrz krytycznych i kooperatywnych (a zatem niekooptacyjnych) kontekstów edukacyjnych procesy uczenia się i kształcenia oferuja szansę na krytykę celów, dla realizacji których intelekt powszechny zostaje utowarowiony, zamiast przekształcić się w to, co publiczne. Dają również możliwość odzyskania i wyzwolenia intelektu powszechnego i zaprzęgnięcia go do realizacji celów kooperatywnego użytku (Manzerolle 2010; Marks 1968).

Dzięki ponownej ocenie konkretnej i abstrakcyjnej pracy akademickiej, szczególnie ich stosunku do intelektualności masowej, można skoncentrować się na alternatywnych praktykach edukacyjnych, rozwijając uspołecznioną wiedzę w charakterze bezpośrednio społecznej siły wytwórczej. Jak twierdzi Arvidsson (2008), tego rodzaju alternatywy pozwalaja na podjęcie starań na rzecz społecznego wyzwolenia nauki i technologii oraz umożliwiaja „,wolny dostęp do intelektu powszechnego w otoczeniu społecznym [co] oznacza, że kapitał nie może sprawować monopolu nad tym zasobem wytwórczym. Można go zastosować dla realizacji autonomicznych, a nawet wywrotowych celów". Praca akademicka może działać jako jeden z krytycznych obszarów w ramach walki o odzyskanie intelektu powszechnego. Dzieje się tak po części wskutek żądania zwrotu publicznych, opartych na chmurach środowisk pozwalających na zglobalizowane upowszechnianie wiedzy na marginesach pracy kapitalistycznej, na przykład poprzez tworzenie edukacyjnych dóbr wspólnych zakorzenionych w krytycznych praktykach pedagogicznych (Bauwens i Iacomella 2012). Może również wyłonić się dzięki wykorzystaniu cyfrowych technologii wewnątrz tworzących wspólnoty alternatywnych układów edukacyjnych w rodzaju okupacji studenckich, centrów kooperacyjnych czy społecznych centrów nauki (Amsler i Neary 2012). Wszystkie te starania dają nam szansę na podjęcie krytyki celów, dla których intelekt powszechny jest dziś raczej przekształcany w towar niż czyniony publicznym.

Istnieje jednak szereg zastrzeżeń w związku z potencjalną fetyszyzacją intelektualności masowej jako kategorii pozwalającej na wyzwolenie ludzkich stosunków z objęć subsumcji jako formy pracy. Jednym z nich jest to, że intelektualność masowa musi zostać usytuowana w ramach krytyki i odpowiedzi na kryzys, którego źródłem są sprzeczności samego kapitalizmu (Bologna 2014; Tomba i Bellofiore 2014). W ramach walki klas moga zaistnieć istotne kontrnarracje właśnie poprzez tę krytykę, a nie wielościowe sposoby odmowy pracy. Podobnie, potencjalna koncentracja na akademiku jako na uspołecznionym robotniku, który pracuje w fabryce społecznej, kosztem skupienia na skolektywizowanym robotniku pracującym i wytwarzającym w obszarze przemysłu, grozi uprzywilejowaniem konkretnej perspektywy, z której ujmuje się klasę robotniczą (Tomba i Bellofiore 2014). Ponowna koncentracja na 
dwoistości konkretnych/abstrakcyjnych rzeczywistości stosunków pracy, wraz ze stosunkami produkcji, stanowi tu kluczowy komponent rozwijania interesujących nas kontrnarracji (Jappe 2014). Mogą one obejmować zarówno odmowę pracy akademickiej w formalnych instytucjach edukacyjnych, rozwijanie akademickich dóbr wspólnych, wykorzystanie wolnego i otwartego oprogramowania, licencje copyleft, jak i urzeczywistnienie sieci peer-to-peer (Bauwens and Iacomella 2012; Free, Libre, Open Knowledge [FLOK] Society 2014; Kleiner 2014).

\section{Wnioski. W stronę możliwości zniesienia pracy akademickiej poprzez intelektualność masową?}

Powiązania między komercyjnymi dostawcami edukacji a uniwersytetami, edukatorami i studentami jako wytwórcami i konsumentami usług edukacyjnych, danych i wytworów, odsłaniaja przed nami hegemonię i zależność. Ta złożona współzależność nie daje się jednak zredukować do sfetyszyzowanych idei zakorzenionych w pieniądzu za pośrednictwem oszczędności kosztów czy emancypacji opartej na kształceniu do życia w ramach kapitalistycznie zorganizowanej pracy. Jednakże rozszerzenie tej hegemonii na kontekst edukacyjny za pośrednictwem subsumcji pracy akademickiej wiąże się z mechanizmami, które zapewniaja reprodukcję kapitału poza jego ograniczeniami i granicami. W całym globalnym obszarze edukacyjnym starania kapitału finansowego i handlowego, by zsynchronizować produkcję edukacyjną w ramach ich własnych obiegów, skutkują ciężką do zniesienia symbiozą. Zaświadczyć mogą o niej wszyscy osobnicy uwikłani w szkolnictwo wyższe w warunkach restrukturyzacji pod dyktando kapitału finansowego oraz nowych rynków (Amsler i Neary 2012; Brook 2009; McGinn 2012).

Reakcja kapitału na kryzys produkcji wartości jest o tyle istotna, że wiąże się z uwagami Marksa (1977) dotyczącymi tego, jak stowarzyszeniowa faza kapitału może sama stworzyć szanse na zaistnienie alternatywnych form społecznie użytecznej pracy czy praktyk. Szanse te maja globalny charakter i opierają się na kooperatywnym oraz demokratycznym zaangażowaniu w społeczeństwo obywatelskie, jak również w obszar tego, co polityczne, obejmujące rynek, państwo, dobra wspólne oraz organizacje trzeciego sektora. Przywodzi to na myśl pracę Bauwensa i Iacomelli (2012) dotyczącą tworzenia kooperatywnych projektów pedagogicznych, które mogą odsłonić alternatywy względem idei nieskończonego wzrostu i materialnej obfitości powiązanej z długiem. Tego rodzaju alternatywy muszą bazować na krytyce idei niematerialnej rzadkości, ustanawianej między innymi przez porozumienia w rodzaju TTIP czy globalne prawo własności intelektualnej. Moga również odrzucić pseudoobfitość powiązaną z grodzeniem i niszczeniem biosfery. Bauwens i Iacomella (2012) argumentuja jednak na rzecz globalnego porozumienia między ruchami opartymi na ideach otwartego dostępu czy copyfarleft, ekologii oraz społecznej sprawiedliwości, jak również globalnej emancypacji. 
W tym miejscu akademicy moga zadać trafne pytanie, jakiego rodzaju działania chcemy kolektywnie podtrzymywać oraz w jaki sposób mogą być one określone, zarządzane i uregulowane? Wymaga to, by różni pracownicy akademiccy, w tym profesorowie zwyczajni i nadzwyczajni, adiunkci czy zatrudnieni tymczasowo wykładowcy, asystenci i tak dalej, byli zdolni do rozważenia raczej momentów solidarności niż podziału. Działania pojawiające się w ramach nowego kooperatyzmu oraz intelektualnego zaplecza projektów pedagogicznych w rodzaju studenta-jako-wytwórcy (Amsler i Neary 2012) czy organizacje w rodzaju Społeczne Centrum Nauki (Social Science Centre 2014) oferują sposób ramowania i rekonceptualizowania potencjału kooperacyjnej alternatywy dla neoliberalizmu dla etapów proto/zwijania/rozwijania. Tego rodzaju prace rzucaja również wyzwanie rzeczywistości konkurencyjnego przekształcania publicznego szkolnictwa wyższego oraz idei głoszącej, że uniwersytet służy zyskowi i pomnażaniu wartości. Upowszechnienie się prokooperacyjnych idei pośród transnarodowych sieci aktywistów może umożliwić ponowne powiązanie pracy akademickiej, jako pracy zachodzącej w obrębie społeczeństwa, w formie pozwalającej na wsparcie intelektualności masowej, a nie prywatnej akumulacji (Virno 2001; Winn 2014a). Jak stwierdzili przedstawiciele Social Science Centre (2014), nadzieja leży w „możliwościach stowarzyszeniowych sieci” poddających krytyce politykę i praktykę szkolnictwa wyższego.

Sformułowana przez Winna (2014a) definicja kooperatywnego współzależnego rządzenia jako czegoś kluczowego w odkreślaniu stowarzyszeniowych sieci stwarza dla tego procesu alternatywną, polityczną i pedagogiczną przestrzeń, wewnątrz której pracy akademickiej można nadać nowy cel, ukierunkowując ją na masową intelektualność. Winn (2014a) twierdzi, że zespalanie demokratycznej regulacji transnarodowych robotniczych kooperatyw z obiegami produkcji oraz podziału gospodarki peer-to-peer wskazuje na kierunek kontrhegemonicznych, „otwartych kooperatywnych” zestawów możliwości. Powstają w ten sposób pedagogiczne momenty, które ugruntowuja otwartą, demokratyczną, autonomiczna, społeczną koncentrację kooperatyw ześrodkowanych na edukacji i tkwiących wewnątrz ramy dla wspólnej własności wytworów, zasobów oraz towarów. Jak twierdzi Winn (2014a): „celem otwartych licencji oraz struktur współzależnego rządzenia »otwartych kooperatyw« jest stworzenie substytutu dla społecznej roli pieniądza w takim sensie, że tworzą one odmienna formę miary wzajemnej ekwiwalencji (pieniądz jest dziś powszechnym ekwiwalentem). Wydaje się, że jest to dobry krok przejściowy w kierunku społecznych stosunków, które nie wymagaja oparcia na jakiejkolwiek uniwersalnej formie ekwiwalencji (tj. od każdego według jego zdolności, każdemu według potrzeb: pozytywna nie-wzajemność)."

Idea otwartej kooperatywy napędzana jest solidarnością zrodzoną raczej z kooperatywnej produkcji aniżeli z podziału i konsumpcji. Ujmując rzecz w kategoriach stosunku między pracą akademicką a intelektualnością masową, należy stwierdzić, że wiąże się ona 
z ukutym przez Sarah Amsler (2013) pojęciem nieustraszonego i ponownie upolitycznionego uniwersytetu:

Jeśli mamy kształtować uniwersytety tak, by stały się miejscami, w których możemy rzeczywiście uczyć i studiować, uczyć się i być [...] musimy kształcić nas samych w zakresie polityki szkolnictwa wyższego, zaawansowanych badań, pracy, kultury intelektualnej, przestrzeni i czasu. Musimy to robić w kontekście, w którym myślenie i mówienie o polityce dotyczącej jakiejkolwiek z tych rzeczy nie jest uznawane ani za stratę czasu, ani za zagrożenie dla ekonomicznej wydajności czy instytucjonalnej „reputacji” [...]. Musimy robić to w otoczeniu, w którym prawdopodobnie wielu akademików, dzięki swojej profesji czy skłonności, nie ma ani żadnego doświadczenia politycznej partycypacji czy aktywizmu, ani w ogóle żadnego zainteresowania społeczna czy gospodarczą polityką. Musimy robić to wszystko w otoczeniu, w którym wielu akademików i niektórzy studenci są wyczerpani, ponieważ znajdują się w niepewnej sytuacji, a zatem potrzebuja znacznej samopomocy i kolektywnego wsparcia. Jest to co najmniej czterowątkowy projekt. Nie powinno nas to jednak zniechęcać; życie jest bowiem skomplikowane.

Wezwanie Amsler (2013) do „troszkę bardziej upolitycznionego stosunku do prawdy w sprawach edukacji, wiedzy i praktyki akademickiej” jest formą samorealizacji, o której pisze bell hooks (1994), to znaczy: zdolności do pełniejszego i głębszego życia. Jest to ludzka zdolność, będąca również umiejętnością do wyzwolenia czasu na działania i akcje solidarnościowe, a nie na wymianę. Życie akademickie nie jest w tym kontekście napędzane przez wycenę towarów opartą na dominacji czasu abstrakcyjnego. Rządzi nim raczej czas użyteczny w stosunku do społecznej reprodukcji. Nie chodzi w nim o wskaźniki wpływu, zarządzanie wydajnością, ocenę czasu zwrotu czy zarządzanie nakładem pracy. Takie życie oparte jest raczej na osobistych i społecznych stosunkach, które demontują bariery dzielące pracę i życie, co pozwala nauczycielowi i studentowi na tworzenie pedagogicznego sojuszu na rzecz kolektywnego, społecznie wynegocjowanego przekraczania władzy kapitału sprawowanej nad uczeniem się, kształceniem i programami studiów. Sojusz ten objawia się wewnątrz-i-przeciwko czasowi abstrakcyjnemu, jest początkiem i końcem pedagogicznej walki o czas wolny oraz przeciwko abstrakcyjnym procesom tworzenia wartości i akumulacji.

Ma to znaczenie, ponieważ, jak odnotowuje McGettigan (2014), mierzymy się z coraz bardziej uogólnionym deficytem demokratycznym wewnątrz instytucji, tak w odniesieniu do idei tego, co publiczne, jak i sposobów finansowania, regulowania i rządzenia uniwersytetami. Jest to dogłębny, jakościowy zwrot, który domaga się politycznego i pedagogicznego zaangażowania umocowanego w współzależnym rządzeniu. Dla Winna (2014b) istnieją w tym kontekście trzy możliwe odpowiedzi powiązane z akademicką produkcja i współzależnym rządzeniem. 
1. Przelesztatcanie: ukonstytuowanie uniwersytetu w oparciu o kooperatywne wartości i zasady;

2. Rozkład: radykalizowanie uniwersytetu od wewnątrz, począwszy od stosunku między akademikami i studentami;

3. Tworzenie: prowadzenie eksperymentów w szkolnictwie wyższym poza sfinansjeryzowanym sektorem.

W ramach każdej z tych odpowiedzi kluczowe staje się to, czy akademicy moga rozwinąć alternatywne metody wyzwalania poznania i wiedzy oraz organizacji, wykraczające poza czasoprzestrzeń wytwarzania wartości czy akumulacji. Zaproponowane przez Winna odpowiedzi uwarunkowane są przez strukturalna dominację pracy najemnej oraz realia, w których funkcjonuja kooperatywne przestrzenie, to znaczy, przez przymus istnienia wewnątrz totalizujących stosunków produkcji społeczeństwa kapitalistycznego. Oferują one jednak alternatywne możliwości wyzwolenia nauki i technologii w obrębie społeczeństwa. Poprzez powiązanie z nieustraszonymi praktykami, które wyrastają z otwartego kooperatyzmu, odpowiedzi te moga na funkcjonować na trzy odmienne sposoby jako krytyczne obszary w walce o masową intelektualność. Po pierwsze, przyczyniając się do odzyskania publicznych, otwartych środowisk umożliwiających zglobalizowane, uspołecznione upowszechnianie wiedzy (Kleiner 2014). Po drugie, wiążąc globalny zestaw edukacyjnych dóbr wspólnych zakorzenionych w praktykach pedagogiki krytycznej. Po trzecie, rozwijając struktury współzależnego rządzenia, które ugruntowuja, krytykują i upowszechniają tworzenie wspólnot w ramach alternatywnych układów edukacyjnych w rodzaju okupacji studenckich, kooperatywnych centrów czy społecznych centrów nauki (Amsler i Neary 2012).

To, czy koncentracja na intelektualności masowej i otwartym kooperatyzmie stanowi potencjalnie przejściowy moment w ruchu zniesienia pracy akademickiej jest kwestią sporną. Jednakże ponowne przemyślenie tego, co konkretne i tego, co abstrakcyjne w kontekście pracy akademickiej poprzez intelektualność masową oraz otwarty kooperatyzm zmusza akademików do zastanowienia się nad własnym stosunkiem do dóbr wspólnych, państwa oraz jego instytucji czy też szerzej do społeczeństwa obywatelskiego. Stosunek ten ma kluczowe znaczenie, gdy usiłujemy zdefiniować postkapitalizm jako pedagogiczny, umocowany historycznie i materialny w swym charakterze moment społeczny. W tym miejscu argument Cumbersa $(2012,156)$ dotyczący tego, że „potrzebne jest bardziej zniuansowane rozumienie dynamicznej natury przestrzennej organizacji i współzależnego rządzenia w warunkach zaawansowanego kapitalizmu" dobrze zestraja się z pracą FLOK Society (2014a). Widać to w Otwartym liście do Commonersów: „Wyobraź sobie społeczeństwo, które powiązane jest z otwartymi dobrami wspólnymi wiedzy w każdym obszarze ludzkiej aktywności, oparte na wolnej i otwartej wiedzy, kodzie oraz wzornictwie, które mogą być wykorzystywane przez wszystkich obywateli na równi z rządem czy graczami rynkowymi, bez żadnej dyskryminacji czy ubezwładnienia, które następują w konsekwencji sprywatyzowania wiedzy". 
Otwarte dobra wspólne wiedzy, stanowiąc przestrzeń dla intelektualności masowej, okazują się szansą dla rzeczywiście istniejącej formy otwartego kooperatyzmu. Takie powiązanie między praca akademicką a intelektualnością masową znalazło swoją realizację w intelektualnym dorobku FLOK Society (2014b) zawartym w General Framework Document, który miał na celu wdrożenie ekwadorskiego Krajowego planu na ręecz, dobrego życia (2009). Chodziło w nim o:

uruchomienie i koordynowanie globalnego procesu partycypacyjnego oraz bezpośredniej krajowej aplikacji na rzecz zmiany wytwórczej matrycy społeczeństwa, zmierzając w kierunku zbudowania społeczeństwa otwartej i wspólnej wiedzy w Ekwadorze. W konsekwencji stworzono 10 podstawowych dokumentów prawnych dotyczących polityk państwa (zsynchronizowanych z organicznym, społecznym kodem dla gospodarki wiedzy), użytecznych dla już istniejących w Ekwadorze sieci wytwórczych wiedzy. W ten sposób zaistniał pojęciowy, filozoficzny i ekonomiczny proces, jak również historyczna i społeczno-poznawcza rama kontekstowa, organizacyjne zasady rządzące procesem, kolaboracyjne i komunikacyjne narzędzia cyfrowe, które umożliwiały zaawansowane planowanie całego procesu.

Omawiany problem można sprowadzić do następujących pytań: czy możliwe jest wykorzystanie takich form pracy intelektualnej jako intelektualności masowej, w celu odzyskania idei tego, co publiczne w obliczu kryzysu wartości? Czy możliwe jest ponowne rozważenie pedagogicznej relacji między tym, co konkretne, a tym co abstrakcyjne, gdy są one reprodukowane globalnie wewnątrz kapitalizmu? Czy można wyzwolić demokratyczną zdolność pracy akademickiej, wpierw jako pracy, a następnie jako transnarodowej, kolektywnej aktywności zachodzącej wewnątrz otwartych kooperatyw, w celu przeorientowania społecznej produkcji i skierowania jej poza wartość, w stronę partycypacyjnego rządzenia i zarządzania produkcją życia codziennego?

Proces ten wymaga negacji urzeczowionej istoty pracy akademickiej, tak by w samym sercu reprodukcji społeczeństwa stały wartości społeczne, a nie wartość [ekonomiczna]. W tym miejscu zainteresowanie Amsler nieustraszonością wiąże się z Cleaverowskim (1993) wezwaniem do rozwijania ,polityki sojuszu przeciwko kapitałowi [...] nie tylko w celu przyspieszenia cyrkulacji walk z sektora do sektora, co raczej by prowadzić ją w sposób pozwalający na zbudowanie postkapitalistycznej polityki różnicy bez antagonizmu". Ponowne upolitycznienie pracy akademickiej może zainicjować proces przekraczania jej wyabstrahowanego i sfetyszyzowanego charakteru. Punkt wyjścia stanowi tu definicja momentu pedagogicznego, który umożliwia ujmowanie cech wpływających i wypływających z pracy akademickiej, już nie w kategoriach wartości, pieniądza oraz towaru, ale w odniesieniu do innego obrazu społeczeństwa i produkcji. Tego rodzaju moment pedagogiczny wymaga tworzenia otwartych, uczestniczących sfer publicznych, potencjalnie znajdujących się wewnątrz otwartych kooperatyw, celując w podtrzymanie rzeczywistego ruchu, który znosi stan obecny. 


\section{Wykaz literatury}

Amsler, Sarah. 2013. „,The Fearless University”. http://amsler.blogs.lincoln.ac.uk/2013/05/16/the-fearless-university/.

Amsler, Sarah i Mike Neary. 2012. „Occupy: a new pedagogy of space and time?”. The Journal for Critical Education Policy Studies 10 (2): 106-38. http://www.jceps.com/PDFs/10-203.pdf.

Arvidsson, Adam. 2008. „Valuing the Ethical Economy”. P2P Foundation. http://p2pfoundation.net/Valuing_the_Ethical_Economy.

Ball, Stephen J. 2012. Global Education Inc. New Policy Networks and the Neo-Liberal Imaginary. London: Routledge.

Bauwens, Michael i Franco Iacomella. 2012. „Peer-to-Peer Economy and New Civilization Centered Around the Sustenance of the Commons". In The Wealth of the Commons: A World Beyond Market and State, red. The Commons Strategy Group. http://wealthofthecommons.org/essay/peer-peer-economy-and-new-civilizationcentered-aroundsustenance-commons.

Bologna, Sergio. 2014. „Workerism: An Inside View. From the Mass-Worker to SelfEmployed Labour". In Beyond Marx: Theorising the Global Labour Relations of the TwentyFirst Century, red. Marcel van der Linden iKarl. H. Roth, 121-44. Leiden: Brill.

Braverman, Harry. 1998. Labour and Monopoly Capital: The Degradation of Work in the Twentieth Century. New York: Monthly Review Press.

Brook, Paul. 2009. „The Alienated Heart: Hochschild's »emotional labour« thesis and the anticapitalist politics of alienation". Capital and Class, 33 (2): 7-31. http://www.uk.sagepub.com/edgell/6.1\%20Brook $\% 20 \% 282009 \% 29 \% 20$ The $\% 20$ alien ated $\% 20$ heart.pdf.

CASA. 2014. „A home online for casual, adjunct, sessional staff and their allies in Australian higher education". http://actualcasuals.wordpress.com/.

Cleaver, Harry. 1993. „Theses on Secular Crisis in Capitalism”. http:/ /libcom.org/library/theses-secular-crisis-capitalism-cleaver.

Cleaver, Harry.2012. Polityczne cåytanie "Kapitału”. Tłum. Iwo Czyż, Poznań: Bractwo Trojka.

Constanti, Panikkos i Paul Gibbs. 2004. „Higher education teachers and emotional labour”. International Journal of Educational Management 18 (4): 243-49.

Cumbers, Andrew. 2012. Reclaiming Public Ownership: Making Space for Economic Democracy. London: Zed Books.

Deem, Rosemary, Sam Hillyard i Mike Reed, red. 2007. Knowledge, Education and New Managerialism. Oxford: Oxford University Press.

Deem, Rosemary, Ka Ho Mok i Lisa Lucas. 2008. „Transforming Higher Education in Whose Image? Exploring the Concept of the »World Class « University in Europe and Asia”. Higher Education Policy 21: 83-97.

FLOK Society. 2014a. „Open Letter to the Commoners’. http://en.wiki.floksociety.org/w/Open_Letter_to_the_Commoners.

FLOK Society. 2014b. „General Framework Document”. http://en.wiki.floksociety.org/w/General_Framework_Document. 
Gartner. 2013. „Gartner Reveals Top Predictions for IT Organizations and Users for 2014 and Beyond". http://gtnr.it/17RLm2v.

Hall, Richard. 2013. „Educational Technology and the Enclosure of Academic Labour Inside Public Higher Education". Journal for Critical Education Policy Studies 11 (3): 52-82. http://www.jceps.com/PDFs/11-3-03.pdf.

Harvey, David. 2010. The Enigma of Capital and the Crises of Capitalism. London: Profile Books. Harvey, David. 2013. A Companion to Marx's Capital: Volume 2. London: Verso.

Hooks, Bell. 1994. Teaching to Transgress: Education as the Practice of Freedom. London: Routledge.

IFS. 2014. „Estimating the Public Cost of Student Loans”. London: IFS. http://www.ifs.org.uk/comms/r94.pdf.

Jappe, Anselm. 2014. „Towards a History of the Critique of Value”. Capitalism, Nature, Socialism 25 (2): 25-37.

Kleiner, Dymitri. 2014. „The Telekommunist Manifesto”. Network Notebooks 03. http://www.networkcultures.org/_uploads/\%233notebook_telekommunist.pdf.

Lipman, Pauline. 2009. „Neoliberal Education Restructuring: Dangers and Opportunities of the Present Crisis". Monthly Review 63 (3). http://bit.ly/qDl6sV.

Manzerolle, Vincent. 2010. „The Virtual Debt Factory: Towards an Analysis of Debt and Abstraction in the American Credit Crisis". tripleC: Cognition, Communication and Cooperation. 10 (2): 221-36.

Marks, Karol. 1977. „Kapitał: Krytyka ekonomii politycznej. Księga II: »Proces cyrkulacji kapitału«. Tłum. J. Maliniak. W Marks, Karol i Fryderyk Engels, Drieła, t. 24, Warszawa: Książka i Wiedza

Marks, Karol. 1986. Zarys krytyki ekonomii politycznej. Tłum. Zygmunt Jerzy Wyrozembski. Warszawa: Książka i Wiedza.

Marks, Karol. 1968. „Kapitał. Krytyka ekonomii politycznej. Księga I: »Proces wytwarzania kapitału«. Tłum. P. Hoffman, B. Minc, E. Lipiński. W Marks, Karol i Fryderyk Engels, Dzieła, t. 23. Warszawa: Książka i Wiedza.

Marks, Karol. 1984. „Kapitał. Krytyka ekonomii politycznej. Księga III: „Proces produkcji kapitalistycznej jako całość«. Tłum. E. Lipiński, J. Maliniak. W Marks, Karol i Fryderyk Engels, Diqieła, t. 25, cz. 1. Warszawa: Książka i Wiedza.

McGinn, Michelle K. 2012. „Introduction to »Belonging and Non-Belonging: Costs and Consequences in Academic Lives«". Workplace 19: 1-3. http://ojs.library.ubc.ca/index.php/workplace/article/view/182370.

McGettigan, Andrew. 2013. The Great University Gamble: Money, Markets and the Future of Higher Education. London: Pluto Press.

McGettigan, Andrew. 2014. „Financialising the University”. Arena Magazine. http://arena.org.au/financialising-the-university/.

Morgan, John. 2013. „Pearson Profits from Private Expansion”. Times Higher Education, November 28. http://www.timeshighereducation.co.uk/news/pearson-profitsfromprivate-expansion/2009372.article. 
Neary, Mike. 2012. „Teaching Politically: Policy, Pedagogy and the New European University". The Journal for Critical Education Policy Studies 10 (2): 233-57. http://www.jceps.com/PDFs/10-2-08.pdf.

Newfield, Christopher. 2013. „Corporate Open Source: Intellectual Property and the Struggle Over Value”. Radical Philosopby 181. http://bit.ly/15sGMt1.

PA Consulting. 2014. „Education”.. http://www.paconsulting.com/industries/governmentand-public-services/education/.PG4FP. 2014.. http://leedspostgrad4fairpay.wordpress.com/.

Postone, Moishe. 1980. "Anti-Semitism and National Socialism: Notes on the German Reaction to »Holocaust«". New German Critique. Special Issue 1: Germans and Jews: 97115.

Postone, Moishe. 1996. Time, Labour and Social Domination: A Reinterpretation of Marx's Critical Theory. Cambridge: Cambridge University Press.

Ravitch, Diane. 2012. „The Pearsonizing of the American Mind”. Accessed June 18, 2014. http://bit.ly/NE1LvB.

The Republic of Ecuador. 2009. „National Plan for Good Living 2009-2013: Building a Plurinational and Intercultural State". http://bit.ly/GQJi0M.

Robinson, William I. 2004. A Theory of Global Capitalism: Production, Class, and State in a Transnational World. Baltimore, MA: John Hopkins University Press.

Snowdon, Chris. 2013. „President's address to 2013 Members' Annual Conference: The enduring value of universities". Universities UK.. http://www.universitiesuk.ac.uk/highereducation/Pages/PresidentsAddress2013Annu alConference.aspx\#.U57giSJnSSp.

The Social Science Centre. 2014. http://socialsciencecentre.org.uk/.

Thompson, Edward P. 1967. Time, Work-Discipline, and Industrial Capitalism. Past and Present. 38 (1): 56-97.

Thorburn, Elise. 2012. „Actually Existing Autonomy and the Brave New World of Higher Education". Occupied Studies. http://bit.ly/xzcPRO.

Tomba, Massimiliano i Riccardo Bellofiore. 2014. The 'Fragment on Machines' and the Grundrisse: The Workerist Reading in Question. In Beyond Marx: Theorising the Global Labour Relations of the Twenty-First Century, red. Marcel. van der Linden i Karl H. Roth, 345-68. Leiden: Brill.

The University of Utopia. 2014. Anti-Curricula: A Course of Action. http://www.universityofutopia.org/sharing.

Virno, Paolo. 2001. „General Intellect”. http://www.generationonline. org/p/fpvirno10.htm.

Virno, Paolo. 2004. A Grammar of the Multitude. Los Angeles, CA: Semiotext(e).

Wendling, Amy E. 2009. Karl Marx on Technology and Alienation. London: Palgrave Macmillan.

Willetts, David. 2013. „Robbins Revisited: Bigger and Better Higher Education”. London: Social Market Foundation. http://www.smf.co.uk/research/categorytwo/robbinsrevisited/.

Willetts, D. 2014. „Contribution of UK universities to national and local economic growth. Department for Business, Innovation and Skills". 
https://www.gov.uk/government/speeches/contribution-of-uk-universities-tonational-and-localeconomic-growth.

Winn, Joss. 2014a. „Open Cooperatives (1)”. http://josswinn.org/2014/06/open-cooperatives-1/.

Winn, Joss. 2014b. „Is the Worker Co-Operative Form Suitable for a University? (Part 3)”. http://josswinn.org/2014/04/is-the-worker-co-operative-form-suitable-forauniversity-part-3/.3 cosas campaign. 2014. http://3cosascampaign.wordpress.com/. 
Richard Hall - profesor w dziedzinie edukacji i technologii pracujący na De Montfort University w Leicester, w Wielkiej Brytanii. Pełni tam funkcję kierownika jednostki zajmującej się rozwijaniem kształcenia w kontakcie z technologią oraz prowadzi Centre for Pedagogic Research. Jest również National Teaching Fellow oraz współpracownikiem Social Science Center z Lincoln w Wielkiej Brytanii. Pisze o życiu w szkolnictwie wyższym na swoim blogu: http:/ / richard-hall.org.

\title{
DANE ADRESOWE:
}

De Montfort University, The Gateway, Leicester, LE1 9BH, United Kingdom

Email: rhall1@dmu.ac.uk

CYTOWANIE: Hall, Richard. 2015. „O zniesieniu pracy akademickiej. Stosunek między pracownikami intelektualnymi a intelektualnością masową." Praktyka Teoretyczna 4 (18): 93-120.

DOI: $10.14746 /$ prt.2015.4.4

\section{AUTHOR: Richard Hall}

TITLE: On the Abolition of Academic Labour: The Relationship Between Intellectual Workers and Mass Intellectuality

\begin{abstract}
This article analyses the ways in which academic labour as a productive activity is subsumed under the circuits and cycles of finance capital. These circuits are redefining universities as transnational associations of capitals, through which the concrete and abstract realities of academic labour are recomposed for value production and accumulation. One way of critiquing and moving beyond such a recomposition is through a reconsideration of academic labour as a fetishised form of labour, subsequently framed in terms of the idea of „mass intellectuality”. The potential for mass intellectuality to enable liberation from the domination of capitalist social relations is contested, but the idea of socially-useful, living knowledge offers a mechanism for rethinking the value of academic labour, and pointing towards its abolition. Thus, the article asks whether it is possible to dissolve academic labour into the fabric of society as intellectual work, through which another image of society and social production becomes possible. Here the ideas of open co-operativism and fearless practice underpin a politics of alliance against capital that seeks to abolish the present state of things.
\end{abstract}

KEYWORDS: academic labour, mass intellectuality, open co-operativism, university, value. 